\title{
Oral solid self-nanoemulsifying drug delivery systems of candesartan citexetil: formulation, characterization and in vitro drug release studies
}

\author{
Halah Hussein Ali ${ }^{*}$ and Ahmed Abbas Hussein
}

\begin{abstract}
Candesartan cilexetil is an ester prodrug antagonist to angiotensin II receptor type 1 (AT1) used in management of many cardiovascular diseases. The absolute bioavailability of candesartan cilexetil is about (14-40\%). Therefore, the paper aim was to prepare and evaluate solid self-nanoemulsifying drug delivery systems for candesartan cilexetil in order to improve its solubility, dissolution and stability. Solubility study was run in different vehicles to select the best excipients for dissolving candesartan cilexetil. Pseudo-ternary phase diagrams were constructed at 1:1, 2:1, 3:1 and 4:1 ratios and four formulations were prepared using various concentrations of cinnamon oil, tween 80 with poloxamer 407 mixture and transcutol HP as oil, surfactant mixture and co-surfactant, respectively. After this step about $(0.2$ milliliter) of each formulation was adsorbed on to two different adsorbent mixtures set which were: avicel 101 with aerosil 200 and avicel 101 with dibasic calcium phosphate anhydrous resulted in eight solid nanoformulations. All prepared formulations were evaluated for particle size distribution, polydispersity index, zeta potential, scanning probe microscopy, Fourier transform infrared spectroscopy, differential scanning calorimetry, X-ray powder diffractometry and in vitro drug dissolution. It was found that release rate and extent for all prepared formulations were significantly higher $(p<0.05)$ than marketed tablet as well as plain drug powder. It could be concluded from the study that self-nanoemulsifying drug delivery system is a promising approach to improve solubility, wettability, dissolution and stability of candesartan cilexetil.
\end{abstract}

Keywords: Candesartan cilexetil, Solubility, Pseudo-ternary phase diagram, Adsorbent mixture, Self-nanoemulsifying drug delivery system, Stability

\section{Background}

Two key steps that affect oral bioavailability of drugs are dissolution and gastrointestinal permeation. These two parameters are dictated by the intrinsic physicochemical properties of the drug, i.e., its aqueous solubility and lipophilicity (Jane et al. 2006). The aqueous solubility of the drug in question is a crucial factor because only drug in solution is destined for possible absorption. Dissolution of drug is largely determined by the aqueous solubility of drug, since a drug must be in solution to exert its beneficial effect (Patel et al. 2012). Good drug candidates should have high solubility and high lipophilicity. Unfortunately,

\footnotetext{
* Correspondence: halahpharma@yahoo.com

Department of Pharmaceutics, College of Pharmacy, Baghdad University, Baghdad, Iraq
}

lipophilicity also translates into high hydrophobicity and poor aqueous solubility (Rahman et al. 2011).

Nanotechnology world opens the field of delivering many of therapeutic agents in such a cell-specific manner with a maximum intrinsic activity of drugs. Therefore, to increase drug's efficacy while decreasing their toxic side effects, it has been projected to encapsulate the drug in a nanocarrier (Fathi et al. 2012). Delivery thereby limiting off-target access, improving the bioavailability of poorly soluble drugs and enhancing intracellular delivery (Maravajhala et al. 2012).

Cardiovascular diseases include arterial diseases affecting the blood supply to the heart or to the brain, or to the peripheral regions of the body (Frayn 2005). Thiazide Diuretics, angiotensin converting enzyme inhibitors (ACE 
inhibitors), AT1 antagonists, $\beta$-blockers and calcium antagonists are drugs of first choice aim to prevent organ damage and reduce mortality rate (Bieger et al. 2005). Since it is a chronic disease, it necessitates long term treatment, but most of antihypertensive drugs available today showed extensive first pass metabolism, variable bioavailability and more frequent times of administration make them an ideal candidate for solid self-nanoemulsifying drug delivery (SSNEDDS) (Muhamad et al. 2014).

Self-nanoemulsifying drug delivery system (SNEDDS) is thermodynamically stable isotropic mixed bag of anhydrous nanoemulsion (NE) which when poured to the aqueous medium under gentle agitation, will self-emulsify to yield either oil-in-water $(\mathrm{o} / \mathrm{w})$ or water-in-oil (w/o) NE usually with globule size less than $200 \mathrm{~nm}$ stabilized by the interfacial film of surfactant/co-surfactant mixture (Smix) (Elgadira and Adam 2014; Soni et al. 2014; Dey et al. 2012). This type of delivery system is expected to improve drug solubility and bioavailability by virtue of their high solubilization and permeation attributes suited for poorly soluble and slowly absorbable drugs (Wadhwa et al. 2012). Indeed, these systems can be converted into solid intermediates by various methods and then filled into capsules or compressed into tablets after mixing with proper tableting excipients (Kalepun et al. 2013).

Candesartan cilexetil (CC) is an ester prodrug antagonist to AT1 receptors used in management of hypertension, heart failure, myocardial infarction and diabetic nephropathy (Sweetman 2009; Kolesar and Vermeulen 2016). It is practically insoluble in water with log P 7.43 and belonging to class II according to biopharmaceutical classification system (BCS) (Darwhekar et al. 2012; Beale et al. 2010). Following oral administration, CC undergoes hydrolysis at the ester linkage to form the active drug, candesartan with absolute bioavailability for candesartan is about $40 \%$ when CC is given as a solution and about $14 \%$ when given as tablets. Peak plasma concentrations of candesartan occur about 3 to 4 hours (h) after oral doses as tablets (Moffat et al. 2011). Candesartan is more than $99 \%$ bound to plasma proteins. It is excreted in urine and bile mainly as unchanged drug and a small amount of inactive metabolites with a terminal elimination half-life of about $9 \mathrm{~h}$ (Husain et al. 2011).

The aim of this research was to design and evaluate different formulations of SSNEDDS using various Smix ratios and adsorbent mixtures in order to achieve an enhancement in $\mathrm{CC}$ solubility, wettability, dissolution and stability for better delivery of $\mathrm{CC}$ through oral cavity to confront problems associated with chronic cardiovascular diseases old dosage forms.

\section{Materials and Methods \\ Materials}

Candesartan cilexetil, poloxamer 188 , poloxamer 407 and, poloxamer 338 were purchased from Shenzhen Nexconn PharmaTechs, LTD. (China). Cinnamon oil was brought from Now food (USA). Tween 80 was purchased from Pure chemistry (Germany). Transcutol HP was purchased from Gattefosse Corporation (USA). Microcrystalline cellulose pH 101(Avicel 101) was provided by Fluka analytical (Ireland). Colloidal silicon dioxide (Aerosil 200) was bought from Hyper-Chem LTD Co. (china). Dibasic calcium phosphate anhydrous was purchased from HiMedia Lab Pvt. LTD (India). All other chemicals used were of analytical grade.

\section{Methods \\ Construction of pseudo-ternary phase diagrams}

Pseudo-ternary phase diagrams of oil, Smix and water were constructed using aqueous titration method. Ratios were chosen in increasing the concentration of surfactant with respect to co-surfactant in 1:1, 2:1, 3:1 and 4:1 ratios. Boundaries of phase diagrams designated the system's three components; one axis representing the aqueous phase, the second for the oil, and the third representing the Smix (Selvam et al. 2013).

\section{Preparation of candesartan cilexetil liquid self- nanoemulsifying drug delivery systems}

Four self-nanoemulsifying liquid formulations of $\mathrm{CC}$ were prepared using tween 80 with poloxamer 407 mixture and transcutol HP at Smix ratios (1:1, 2:1, 3:1 and 4:1) keeping oil: Smix at 1:9 ratio as presented in (Table 1). Preparation includes dissolving CC in cinnamon oil, mixing with other components at the concentration of $(8$ milligram $(\mathrm{mg})$ of CC/0.2 milliliter $(\mathrm{ml})$ of SNEDDS) in screw-capped glass vials. The vials were then sealed and placed in a water bath at $\left(50-60{ }^{\circ} \mathrm{C}\right)$ to facilitate homogenization. The components were mixed by vortex mixer (Labinco L46, CAT.NO.46000, Netherland) for 5 minute ( $\mathrm{min}$ ) to obtain clear uniform mixtures and again cooled to room temperature followed by equilibrating the mixture on a sonicator (VWR ultrasonic

Table 1 Composition of candesartan cilexetil liquid self-nanoemulsifying drug delivery systems (\% w/w)

\begin{tabular}{llllccc}
\hline F-code & Smix ratio & Oil:Smix & Cinnamon oil \% & Tween 80\% & Poloxamer 407\% & Transcutol HP \% \\
\hline SNEDDS-1 & $1: 1$ & $1: 9$ & 10 & 36.0 & 9.0 & 12.0 \\
SNEDDS-2 & $2: 1$ & $1: 9$ & 10 & 48.0 & 54.0 & 30.0 \\
SNEDDS-3 & $3: 1$ & $1: 9$ & 10 & 57.6 & 13.5 & 22.5 \\
SNEDDS-4 & $4: 1$ & $1: 9$ & 10 & 14.4 & 18.0 \\
\hline
\end{tabular}


cleaner, USC200T model, Copley scientific, U.K.) at room temperature for $10 \mathrm{~min}$, after that the formulations were kept under visual observation for at least $48 \mathrm{~h}$ and examined for any signs of turbidity or phase separation prior to particle size distribution studies (Prajapati et al. 2013).

\section{Evaluations of the prepared candesartan cilexetil liquid self-nanoemulsifying drug delivery systems \\ Thermodynamic stability studies}

All of the self-nanoemulsifying liquid formulations were subjected to centrifugation test at 3500 revolutions per minute (rpm) for $30 \mathrm{~min}$. These formulations that keep their clarity were engaged in heating/cooling cycles test with storage time period for about $48 \mathrm{~h}$ at $45{ }^{\circ} \mathrm{C}$ and $4{ }^{\circ} \mathrm{C}$, respectively. Lastly, freezing/thawing cycles test was achieved via storing each prepared formula at $-21{ }^{\circ} \mathrm{C}$ and $+25{ }^{\circ} \mathrm{C}$ for two days at each temperature. All thermodynamically stable formulations were taken for further tests (Kumar et al. 2009; Sureshkumar et al. 2015).

\section{Determination of particle size distribution and polydispersity index value}

The mean particle size distribution and the polydispersity index of the selected liquid SNEDDS formulations were performed by laser particle size analyzer instrument (Brookhaven Corp 90 Plus, NY, USA) at $25^{\circ} \mathrm{C}$ with an angle of detection of $90^{\circ}$ (Tiwari and Amiji 2006).

\section{Measurement of surface charge}

To predict the stability of NE pre-concentrate, the electronic charge of particles in liquid SNEDDS was verified using zeta plus instrument (Brookhaven Zeta Plus, Holtsville, NY 11742-1832, USA). Particles with zeta potentials above 30 millivolt $(\mathrm{mV})$ irrespective of their charge are normally considered stable (Gupta et al. 2011).

\section{Determination of self-emulsification efficiency of surfactant mixture and co-surfactant}

Surfactant mixture (tween 80 with poloxamer 407 mixture at 4:1 ratio) and co-surfactant (transcutol HP) were screened for their cinnamon oil emulsification ability. Surfactant emulsification efficiency was done on the basis of percentage transparency and ease of emulsification judged by the number of flask inversions required to yield a homogenous NE. Briefly, $300 \mathrm{mg}$ of the surfactant mixture was added to $300 \mathrm{mg}$ of cinnamon oil. The mixtures were gently heated at $50{ }^{\circ} \mathrm{C}$ for homogenization of components. From each mixture, $50 \mathrm{mg}$ was then diluted with deionized water to $50 \mathrm{ml}$ in a stoppered conical flask (Yasser et al. 2013).

Formed mixtures were allowed to stand for $2 \mathrm{~h}$ and their percentage transparency was evaluated at $650 \mathrm{~nm}$ by Ultraviolet/Visible (UV/Vis) spectrophotometer (UV6100 PC, EMC lab, Germany) using deionized water as a blank. The resulted combinations were further observed visually for any turbidity or phase separation. Screening of co-surfactant was conducted via preparing a mixture of $100 \mathrm{mg}$ of the co-surfactant, $200 \mathrm{mg}$ of the selected surfactant mixture and $300 \mathrm{mg}$ of the selected oil and evaluated in the same way as the surfactant mixture (Yasser et al. 2013).

\section{Determination of self-nanoemulsification time}

The emulsification times of prepared CC SNEDDSs were determined using united state pharmacopeia (USP) type II dissolution apparatus (UV-6100 PC, EMC lab, Germany). About $(0.2 \mathrm{ml})$ quantity of each formulation was added to $900 \mathrm{ml}$ of 0.1 normal " $\mathrm{N}$ " $\mathrm{HCl}(\mathrm{pH} 1.2)$ at $37{ }^{\circ} \mathrm{C}$. The formed mixtures were gently stirred at $50 \mathrm{rpm}$ and visually monitored (i.e., until a transparent homogenous system was seen) to determine the time (min) for complete nanoemulsification according to the visual observation criteria for self NE formation listed in (Table 2). The upper limit for formation of good (transparent) NE was set as one min, since when nanoemulsification occurs slowly in more than one min, milky NE with dull appearance will be formed (Yadav et al. 2014).

\section{Robustness to dilution}

Robustness to dilution was evaluated by diluting all formulations 100 and 1000 times with different dissolution media which were: $0.1 \mathrm{~N} \mathrm{HCl}(\mathrm{pH} 1.2)$, phosphate buffer $(\mathrm{pH}$ 6.8) and water. The diluted NEs were stored for $24 \mathrm{~h}$ and monitored for any signs of phase separation or drug precipitation. Formulae which give neither drug precipitation nor phase separation and are thus, said to be "robust" to dilution (Elnaggar et al. 2009).

\section{Turbidity measurement}

Turbidity of the resultant NEs given in a nephelometric turbidity unit (NTU) was measured using a turbidimeter (TurbiDirect, Lovibond, U.K). Turbidity measurements were performed on the NEs stored in screw capped sample vials. A quantity about $0.2 \mathrm{ml}$ of each SNEDDS was introduced into $900 \mathrm{ml}$ of $0.1 \mathrm{~N} \mathrm{HCl}(\mathrm{pH} \mathrm{1.2)} \mathrm{under} \mathrm{the}$ action of gentle magnetic stirring (CB 162 heat-stir,

Table 2 Visual observation of self- nanoemulsification grades

\begin{tabular}{lll}
\hline Grade & $\begin{array}{l}\text { Time required for } \\
\text { nanoemulsion formation }\end{array}$ & Appearance \\
\hline A & Within $1 \mathrm{~min}$ & Clear or slightly bluish \\
B & Within $1 \mathrm{~min}$ & $\begin{array}{l}\text { Bluish white } \\
\text { Bluish white, similar in appearance } \\
\text { to milk }\end{array}$ \\
C & Within 2 min & $\begin{array}{l}\text { Dull, ash emulsion, slightly oily } \\
\text { appearance }\end{array}$ \\
E & Longer than 2 min & $\begin{array}{l}\text { Poor or minimal emulsification, large } \\
\text { oil droplets present on the surface }\end{array}$ \\
\hline
\end{tabular}


Stuart, Copley scientific, U.K.) rotates under a constant speed at room temperature (Dash et al. 2015).

\section{Preparation of candesartan cilexetil solid self- nanoemulsifying drug delivery systems}

self-nanoemulsifying powders (Table 3 ) for CC were prepared by mixing about $(0.2 \mathrm{ml})$ amount of each liquid SNEDDS with two types of an adsorbent mixture in a fixed ratio (40:1). Adsorbent mixtures used were: avicel pH 101 plus aerosil 200 and avicel 101 plus dibasic calcium phosphate anhydrous for a period of $10 \mathrm{~min}$ under gentle magnetic stirring (CB 162 heat-stir, Stuart, Copley scientific, U.K.). Then each prepared mixture was left to dry in an oven at $40{ }^{\circ} \mathrm{C}$ for a period of $48 \mathrm{~h}$. After drying, a quantity of this system $(310 \mathrm{mg})$ equivalent to $8 \mathrm{mg}$ of CC was taken and filled into hard gelatin capsule size 0 (Tarkase et al. 2014).

\section{Evaluations of candesartan cilexetil solid self- nanoemulsifying drug delivery systems Determination of powder flowing properties}

1. Measurement of angle of repose Angle of repose is an angle between the sides of cone and horizontal surface after pouring powder through a funnel onto a horizontal surface (Aulton and Taylor 2013). The angle is a measure of cohesiveness of powder, as it represents the point at which the interparticle attraction exceeds the gravitational pull on a particle and depends on particle size, shape and moisture content (Lachman and Lieberman 1990). A free-flowing powder will form a cone with shallow sides, and hence a low angle of repose, while a cohesive powder will form a cone with steeper sides. The value obtained was calculated using Eq. 1 and compared with ranges sited in (Table 4) (Chavda et al. 2013).

Table 3 Compositions of candesartan cilexetil solid selfnanoemulsifying drug delivery systems

\begin{tabular}{llllll}
\hline F-code & $\begin{array}{l}\text { Smix } \\
\text { ratio }\end{array}$ & $\begin{array}{l}\text { Oil: Smix } \\
\text { ratio }\end{array}$ & $\begin{array}{l}\text { Avicel } 101 \\
\text { (mg) }\end{array}$ & $\begin{array}{l}\text { Aerosil } 200 \\
\text { (mg) }\end{array}$ & $\begin{array}{l}\text { Dibasic calcium } \\
\text { phosphate } \\
\text { anhydrous (mg) }\end{array}$ \\
\hline SSNEDDS-1 & $1: 1$ & $1: 9$ & 200 & 5 & - \\
SSNEDDS-2 & $1: 1$ & $1: 9$ & 200 & - & 5 \\
SSNEDDS-3 & $2: 1$ & $1: 9$ & 200 & 5 & - \\
SSNEDDS-4 & $2: 1$ & $1: 9$ & 200 & - & 5 \\
SSNEDDS-5 & $3: 1$ & $1: 9$ & 200 & 5 & - \\
SSNEDDS-6 & $3: 1$ & $1: 9$ & 200 & - & 5 \\
SSNEDDS-7 & $4: 1$ & $1: 9$ & 200 & 5 & - \\
SSNEDDS-8 & $4: 1$ & $1: 9$ & 200 & - & 5 \\
\hline
\end{tabular}

Table 4 Powder flowing properties based on angle of repose

\begin{tabular}{lll}
\hline No. & $\begin{array}{l}\text { Angle of repose } \\
\text { (degrees) }\end{array}$ & Type of flow \\
\hline I & $25-30$ & Excellent \\
II. & $31-35$ & Good \\
III. & $36-40$ & Fair (flow aid not needed) \\
IV. & $41-45$ & $\begin{array}{l}\text { Passable (may hang up, flow aid might be } \\
\text { needed) }\end{array}$ \\
V. & $46-55$ & Poor (agitation or vibration needed) \\
VI. & $56-65$ & Very poor \\
VII. & Over 66 & Very, very poor \\
\hline
\end{tabular}

$\tan \theta=\mathrm{h} / \mathrm{r}$

Where: $\mathrm{h}$ and $\mathrm{r}$ are height and radius of powder cone; respectively.

2. Measurement of poured density and bulk density A quantity of 2 gram (g) of SSNEDDS powders was poured into $10 \mathrm{ml}$ measuring graduated cylinder. Initial volume was recorded and the cylinder was allowed to fall under its own weight onto a hard surface from a height of 2.5 centimeter $(\mathrm{cm})$ at 2 second intervals. Tapping was continued until no further change in volume (Reddy and Sowjanya 2015). Both densities were calculated using Eqs. 2 and 3.

Poured density $(\mathrm{BD})=\frac{\text { Weight of powder blend }}{\text { Poured volume of powder blend }}$.

Tapped density $(\mathrm{TD})=\frac{\text { Weight of powder blend }}{\text { Tapped volume of powder blend }}$

3. Measurement of Hausner's ratio and Carr's index (Compressibility index)

Hausner's ratio and Carr's index are two terms give a useful measure of powder flowability and calculated using Eqs. 4 and 5 respectively which are illustrated below. Hausner's ratio is related to interparticulate friction and varies from about 1.2 for free-flowing powders to 1.6 for cohesive powders (Table 5) (Lachman and Lieberman 1990). Carr's index is a direct measure of the potential powder arch or bridge strength and stability. It is classified into ranges as listed in (Table 5) (Mohanrao et al. 2011).

$$
\text { Hausner's ratio }=\frac{\text { Tapped bulk density }}{\text { Poured bulk density }}
$$


Table 5 Powder flowing properties based on Carr's index and Hausner's ratio

\begin{tabular}{llll}
\hline No. & Carr's index \% & Hausner's ratio & Type of flow \\
\hline I & $1-10$ & $1.00-1.11$ & Excellent \\
II. & $11-15$ & $1.12-1.18$ & Good \\
III. & $16-20$ & $1.19-1.25$ & Fair \\
IV. & $21-25$ & $1.26-1.34$ & Passable \\
V. & $26-31$ & $1.35-1.45$ & Poor \\
VI. & $32-37$ & $1.46-1.59$ & Very poor \\
VII. & $>38$ & $>1.60$ & Very, very poor \\
\hline
\end{tabular}

Smix 1:1

a

Transcutol HP

Smix 3:1

C
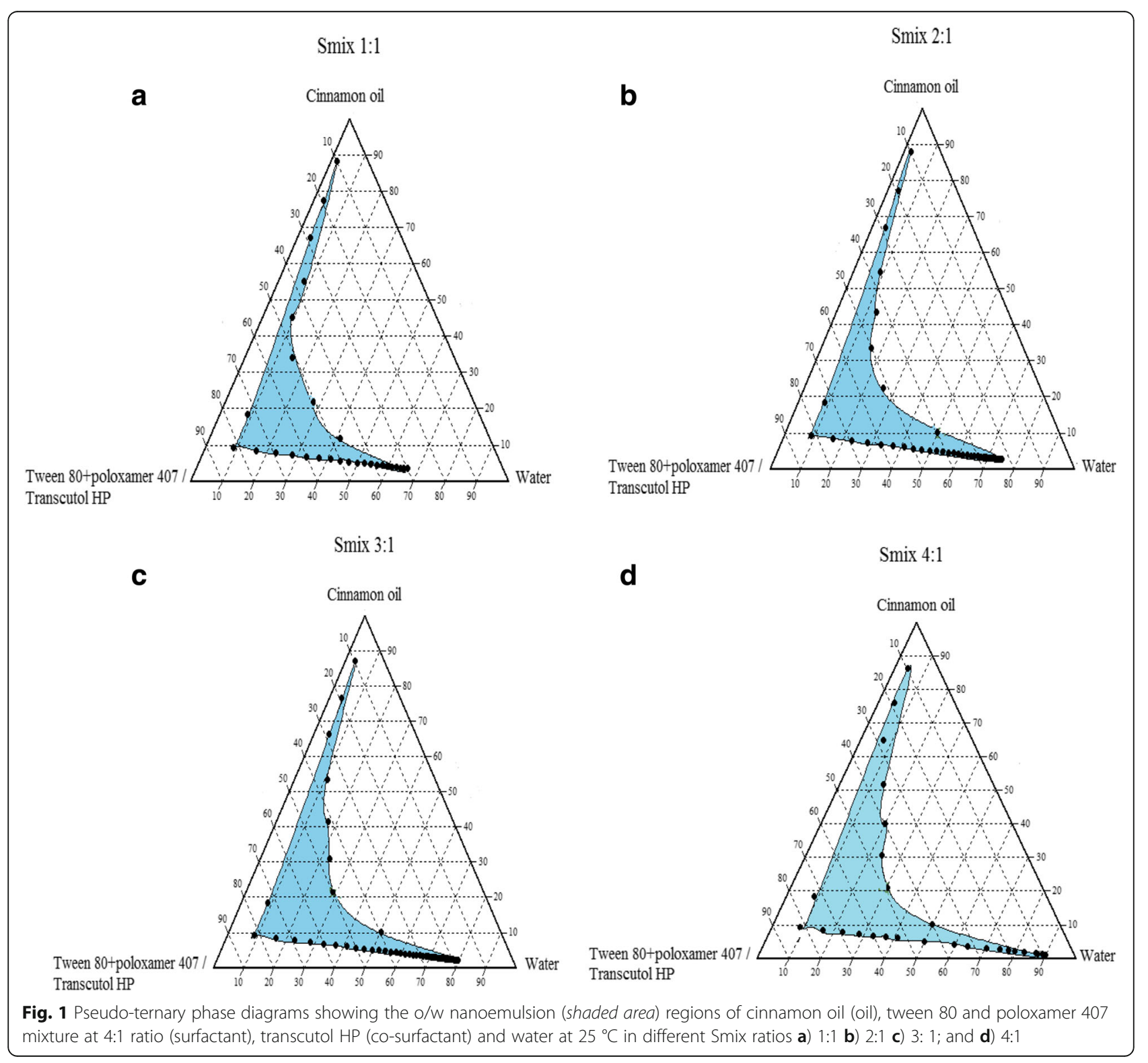

Carr's index $=\frac{100 \times(\text { tapped bulk density-poured bulk density })}{\text { Tapped bulk density }}$

In vitro drug dissolution and kinetics of release in various media In vitro dissolution test was conducted to evaluate the impact of various types of adsorbent mixture on the dissolution of $\mathrm{CC}$ from solid self-nanoemuslifying capsule formulations. Release of $\mathrm{CC}$ from the prepared capsules was determined using USP dissolution apparatus II (DIS 6000, Copley scientific, U.K.) (Paddle type) in $900 \mathrm{ml}$ of $0.1 \mathrm{~N} \mathrm{HCl}$ solution (pH 1.2) (Vuddisa et al. 2014; Krishna et al. 2013). After that, release medium was changed into phosphate buffer ( $\mathrm{pH}$ 6.8) and then into the water in order 
Table 6 Particle size distribution and polydispersity index (PDI) of candesartan cilexetil self-nanoemulsifying drug delivery systems

\begin{tabular}{lll}
\hline F-code & Particle size $(\mathrm{nm})$ & PDI \\
\hline SNEDDS-1 & 39.8 & 0.281 \\
SNEDDS-2 & 22.3 & 0.304 \\
SNEDDS-3 & 14.1 & 0.276 \\
SNEDDS-4 & 46.5 & 0.328 \\
\hline
\end{tabular}

to study the effect of changing the dissolution medium on drug release from SSNEDDS and evaluate its efficacy.

\section{Selection of optimum candesartan cilexetil solid self-} nanoemulsifying drug delivery system

The choice of the best CC SSNEDDS formula was achieved based on the results gained from the evaluation tests including: angle of repose, Hausner's ratio, Carr's index and in vitro drug release study.

\section{Optimum candesartan cilexetil solid self-nanoemulsifying drug delivery system further evaluations Morphology examination}

To visualize the shape and morphology of CC SSNEDDS best formula, the external structure was investigated by a scanning probe microscope (SPM-AA3000, Angstrom Advanced Inc, USA) uses the interaction between a sharp tip and a surface to obtain the image (Thassu et al. 2007).

\section{Fourier transform infrared spectroscopy (FT-IR)}

This test was performed at the range of $4000 \mathrm{~cm}^{-1}$ to $500 \mathrm{~cm}^{-1}$ to detect drug-excipients interaction using FT-IR instrument (FTIR- 8400S, Bruker, Germany). The FT-IR was performed for a pure drug $(\mathrm{CC})$ and optimum SSNEDDS to check if there is any incompatibility between drug and the whole system (Mehta et al. 2014).

\section{Differential scanning calorimetry (DSC)}

The DSC technique was used to acquire qualitative information about the physicochemical status of the drug in the solid NE formula and compatibility problems. Moreover, this test was done in order to assess the thermotropic properties and thermal behavior of the drug (CC) and formula. Procedures include taking about $10 \mathrm{mg}$ of each sample, sealing it in an aluminum pan in

Table 7 Surface charge measurement of candesartan cilexetil self-nanoemulsifying drug delivery systems

\begin{tabular}{ll}
\hline F-code & Zeta potential $(\mathrm{mV})$ \\
\hline SNEDDS-1 & -88.44 \\
SNEDDS-2 & -91.26 \\
SNEDDS-3 & -96.50 \\
SNEDDS-4 & -98.68 \\
\hline
\end{tabular}

Table 8 Efficiency of surfactant/co-surfactant for cinnamon oil self-emulsification

\begin{tabular}{llll}
\hline No. & Surfactant/co-surfactant & Transparency \% & $\begin{array}{l}\text { No. of flask } \\
\text { inversion }\end{array}$ \\
\hline I. & $\begin{array}{l}\text { Tween } 80 \text { with poloxamer } \\
\text { 407 mixture at (4:1) ratio }\end{array}$ & $98.6333 \pm 0.5507$ & 1 \\
II. & Transcutol HP & $99.7000 \pm 0.2645$ & 1 \\
\hline
\end{tabular}

DSC instrument (DSC-60 plus Shimadzu, Japan) and heated at the rate of $10{ }^{\circ} \mathrm{C} / \mathrm{min}$, covering a temperature range of $40{ }^{\circ} \mathrm{C}$ to $300{ }^{\circ} \mathrm{C}$ (Kamalakkannan et al. 2013).

\section{$X$-ray powder diffractometry (XPRD)}

It has been shown that polymorphic changes of drug and drug-excipients interaction are important factors, which may affect the drug dissolution rate and bioavailability; therefore XPRD measurements were carried out on two samples include pure CC powder and optimum SSNEDDS using a diffractometer (XRD-6000 Shimadzu, Japan) covering a range of about $0-50^{\circ}(2 \theta)$ using the $\mathrm{Cu}$-target $\mathrm{X}$ ray tube and Xe-filled detector and relies on the fact that this radiation has a strong penetrating power in materials with the rate of absorption depending on the density of material (Giannini et al. 2016; Vinay and Ahmed 2015).

\section{Stability study}

Optimized CC solid NE formulation was stored at $40{ }^{\circ} \mathrm{C}$ and maintained at $75 \pm 5 \%$ relative humidity (RH) for 3 months (Memmert oven, W. Germany) and examined for particle size, polydispersity index, zeta potential and in vitro drug dissolution on days 0 and 90. The expiration date was also measured from applying the Arrhenius plot method (Yadav et al. 2014; Selvam and Kulkarni 2014).

\section{Statistics}

One-way-analysis of variance (ANOVA) was employed to identify insignificant factors. Data were analyzed and assumed to have an insignificant term when $P>0.05$ and significant term when $P<0.05$.

\section{Results and discussion}

\section{Construction of pseudo-ternary phase diagrams}

Pseudo-ternary phase diagram was used as a useful tool to evaluate the NE domain at Smix ratios: 1:1, 2:1, 3:1 and 4:1. Pseudo-ternary phase diagram results are shown in (Fig. 1).

Table 9 Time of nanoemulsification of candesartan cilexetil liquid self-nanoemulsifying drug delivery systems

\begin{tabular}{lll}
\hline F-code & Grade & Emulsification time (second) \\
\hline SNEDDS-1 & A & 25 \\
SNEDDS-2 & A & 22 \\
SNEDDS-3 & A & 17 \\
SNEDDS-4 & A & 30 \\
\hline
\end{tabular}




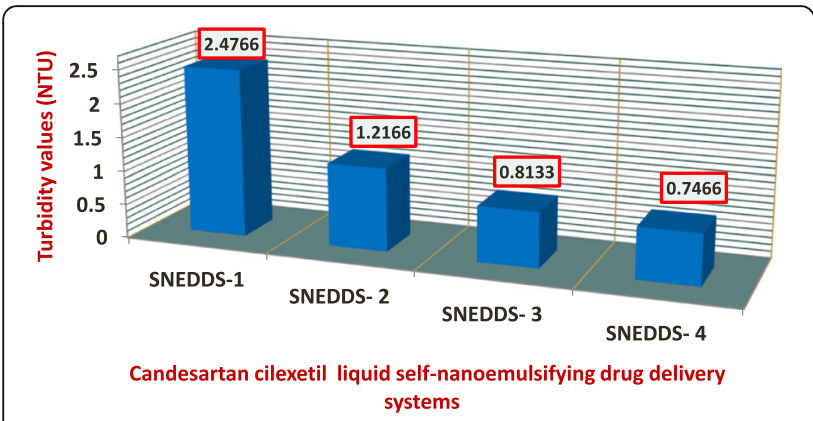

Fig. 2 Chart of turbidity results of candesartan cilexetil liquid self nanoemulsifying drug delivery systems

In each Smix ratio, when tween 80 was mixed with poloxamer 407 in 4:1 ratio, it resulted in final hydrophilic/lipophilic balance (HLB) values of 10.150, 12.100, 13.075 and 13.660 for each Smix ratio used respectively.

\section{Preparation of candesartan cilexetil liquid self-} nanoemulsifying drug delivery systems

Yellow and clear mixtures were apparently observed without drug precipitation or phase separation. In this study, it was found that lower cinnamon oil and higher tween 80 with poloxamer 407 mixture ratio provided a wide transition window from anhydrous to transparent stable NE upon aqueous dilution under gentle magnetic stirring than did the reverse case and resulted in four successful formulations.

\section{Evaluations of prepared candesartan cilexetil liquid self-nanoemulsifying drug delivery systems \\ Thermodynamic stability studies}

Four CC liquid SNEDDSs have passed the successive cycles of centrifugation, heating-cooling test and freezingthawing test. It could be concluded that all formulae were found to be thermodynamically/physically stable systems and were selected for further study.

\section{Determination of particle size distribution and polydispersity index value}

Results obtained (Table 6) showed that, the average particle size can dramatically decrease with increasing surfactant mixture level due to the presence of more surfactant at the cinnamon oil-water interface, thereby providing stabilized NE (Eid et al. 2013). It was evident from the results that when Smix ratio reached (4:1), there was an increase in particle size distribution.

This finding could be explained by the interfacial break up introduced by the extensive aqueous penetration into cinnamon oil droplets enhanced by the increased surfactant level which lead to the ejection of oil droplets into water have lower critical micelle concentrations (Bandyopadhyay et al. 2013).

\section{Measurement of surface charge}

It was found from results illustrated in (Table 7) that the surface charge increased with an increase in surfactant mixture concentration. This could be explained by the fact that higher amount of surfactant (tween 80 with poloxamer 407 mixture) raise the numbers of the hydroxyl group of fatty acid and glycol of tween 80 and poloxamer 407, respectively which further elevate CC SNEDDSs negativity (Ahmad et al. 2014).

\section{Determination of emulsification efficiency of surfactant and co-surfactant}

Results are shown in (Table 8). It was seen that although the cinnamon oil, tween 80 with poloxamer 407 mixture and transcutol HP were miscible with each other, upon emulsification in aqueous phase, the co-surfactant (with low HLB) as the oil may have had better interaction with the oil than did the surfactant mixture (with high HLB) and the oil. The polar head groups of both tween 80 and poloxamer 407 may have extended towards the aqueous phase and interacted more efficiently than transcutol HP (Bouchemal et al. 2004).

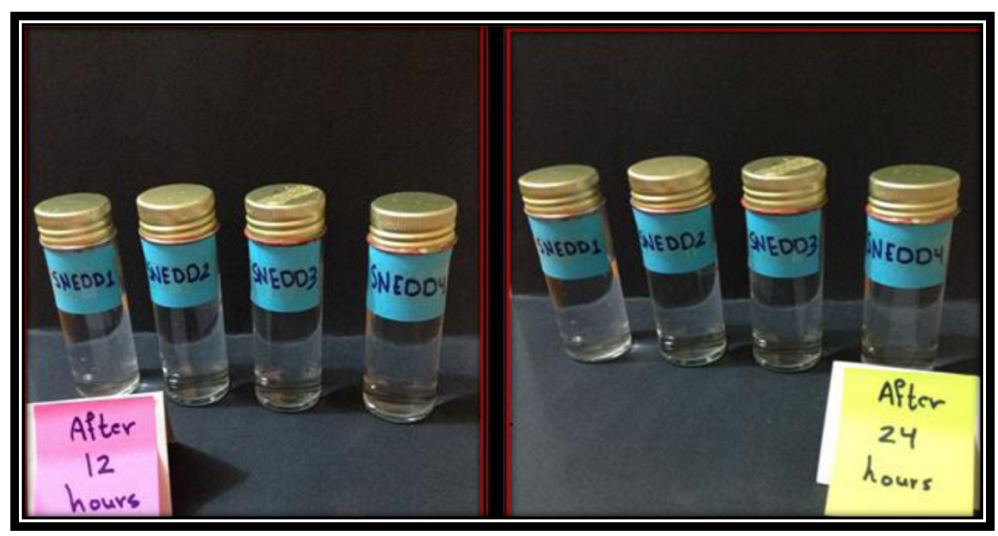

Fig. 3 Photographic picture of turbidity study results of candesartan cilexetil liquid self-nanoemulsifying drug delivery systems 
Table 10 Results of candesartan cilexetil self-nanoemulsifying powder flowing properties evaluation

\begin{tabular}{|c|c|c|c|c|c|c|}
\hline F-code & Angle of repose $(\Theta)$ & Result & Hausner's ratio & Result & Carr's index \% & Result \\
\hline SSNEDDS-1 & $26.5219 \pm 0.4177$ & Excellent & $1.0857 \pm 0.0084$ & Excellent & $7.6456 \pm 0.1869$ & $\overline{\text { Excellent }}$ \\
\hline SSNEDDS-2 & $28.7171 \pm 0.1557$ & Excellent & $1.1106 \pm 0.0004$ & Excellent & $9.6397 \pm 0.3722$ & Excellent \\
\hline SSNEDDS-3 & $27.3802 \pm 0.2573$ & Excellent & $1.0489 \pm 0.0216$ & Excellent & $6.3017 \pm 0.2914$ & Excellent \\
\hline SSNEDDS-4 & $27.6408 \pm 0.2956$ & Excellent & $1.1102 \pm 0.0010$ & Excellent & $8.0971 \pm 0.1610$ & Excellent \\
\hline SSNEDDS-5 & $25.2672 \pm 0.0243$ & Excellent & $1.0416 \pm 0.0175$ & Excellent & $4.3190 \pm 0.0928$ & Excellent \\
\hline SSNEDDS-6 & $25.6616 \pm 0.0318$ & Excellent & $1.0643 \pm 0.0044$ & Excellent & $6.4776 \pm 0.2098$ & Excellent \\
\hline SSNEDDS-7 & $25.1833 \pm 0.0060$ & Excellent & $1.0349 \pm 0.0043$ & Excellent & $3.4751 \pm 0.4301$ & Excellent \\
\hline SSNEDDS-8 & $25.5906 \pm 0.2049$ & Excellent & $1.0559 \pm 0.0083$ & Excellent & $5.8421 \pm 0.0863$ & Excellent \\
\hline
\end{tabular}

\section{Determination of self-nanoemulsification time}

The spontaneity of the nanoemulsification process depends mainly on the following variables: degree of reduction in the interfacial tension, phase transition region and surfactant concentration (Ebrahimi et al. 2013). The assessment of nanoemulsification time showed that with the increase in surfactant mixture concentration, the time needed for nanoemulsification would be reduced. This could be justified via the increase in surfactant contents availability for adsorption and form a film at the oil/water interface (Shafiq and Shakeel 2009).

The study of emulsification time showed that all four formulations employed could emulsify within the range of (17-30) second and were of grade A class (Table 9).

\section{Robustness to dilution}

All CC liquid SNEDDS formulations did not show any signs of phase separation or drug precipitation after $24 \mathrm{~h}$ and $48 \mathrm{~h}$ storage. It was warranted that dilution of liquid SNEDDS does not change the rigidity of packing of surfactant mixture layer at the nanodroplet interface (Prabhakar et al. 2013; Raval et al. 2012).

\section{Turbidity measurement}

It was noticed from the results presented in (Fig. 2), that increasing Smix ratio leads to a decrease in turbidity values due to a better solubility of drug (Sarkar and Hardenia 2011). The formulation with a high turbidity $(2.4766 \pm 0.1266$ NTU) had Smix ratio of (1:1), whereas minimum turbidity result $(0.7466 \pm 0.0251 \mathrm{NTU})$ was found in SNEDDS-4 formulation corresponding to (4:1) ratio. Results showed that all the SNEDDS formulations showed minimum turbidity values (less than $100 \mathrm{NTU})$ in comparison to water $(0.6033$ $\pm 0.0568 \mathrm{NTU})$ as a result of their small particle size, which indicates good miscibility and self-emulsification of theses formulae when introduced into the aqueous acidic medium

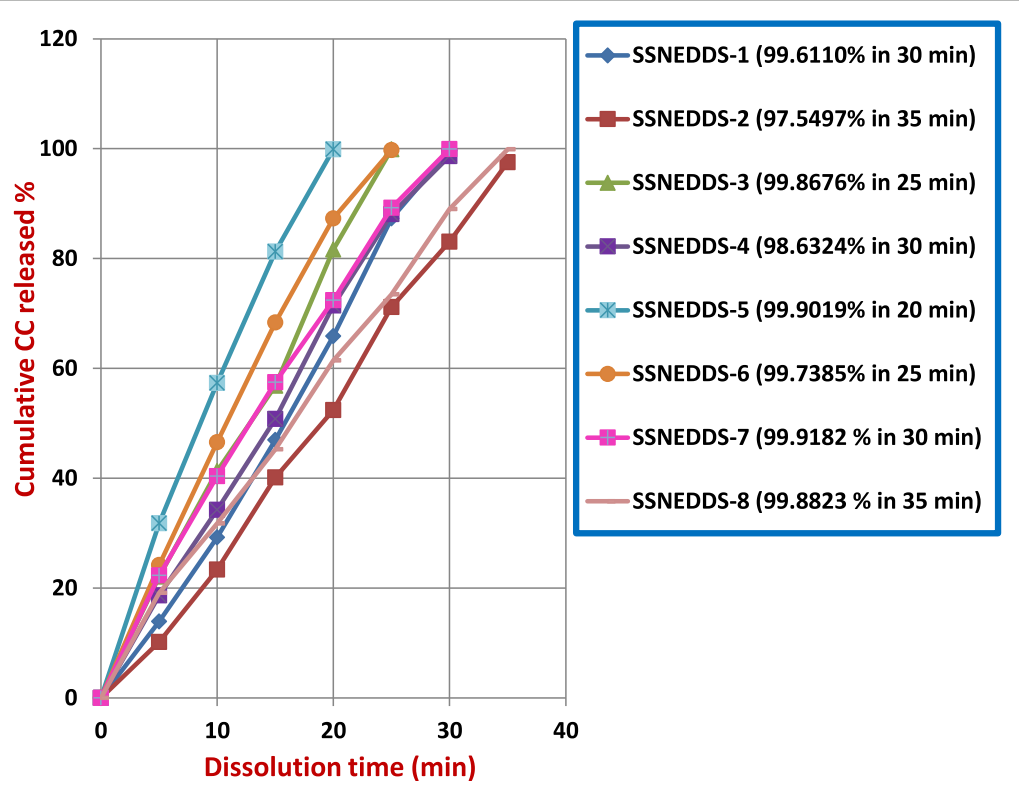

Fig. 4 A comparative dissolution profile of CC in SSNEDDS-1, SSNEDDS-2, SSNEDDS-3, SSNEDDS-4, SSNEDDS-5, SSNEDDS-6, SSNEDDS-7 and SSNEDDS8 in $900 \mathrm{ml}$ of $0.1 \mathrm{~N} \mathrm{HCl}(\mathrm{pH} 1.2)$ with $0.5 \%$ tween 20 at $37^{\circ} \mathrm{C}$ 

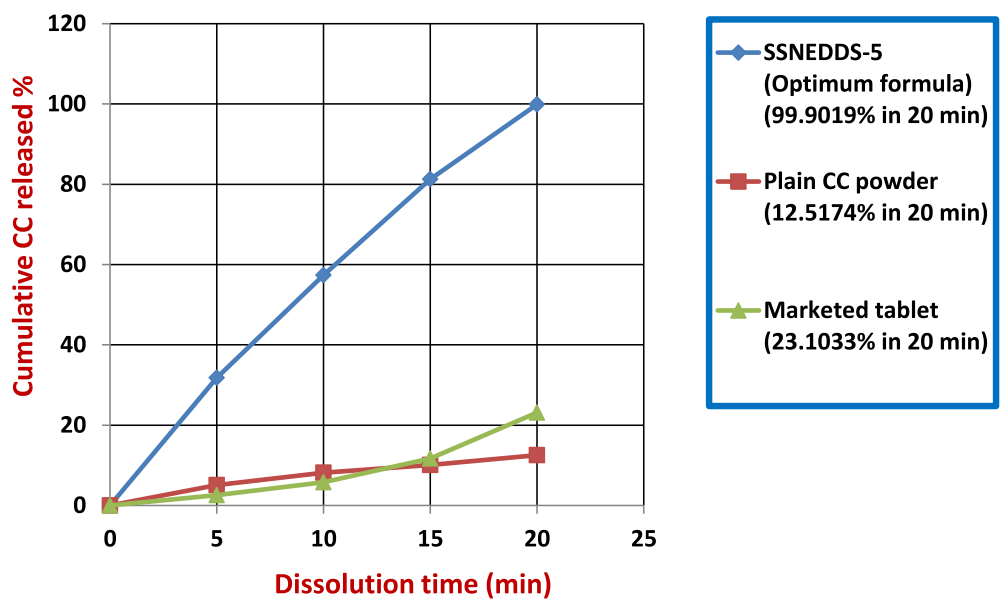

Fig. 5 A comparative dissolution profile of candesartan cilexetil SSNEDDS-5, plain candesartan cilexetil powder and marketed tablet in $900 \mathrm{ml}$ of $0.1 \mathrm{~N} \mathrm{HCl}\left(\mathrm{pH} \mathrm{1.2)}\right.$ with $0.5 \%$ tween 20 at $37^{\circ} \mathrm{C}$

(Czajkowska-Kośnik et al. 2015; Kassem et al. 2010). All prepared liquid formulations maintained their clarity after $24 \mathrm{~h}$ and $48 \mathrm{~h}$ storage as illustrated in (Fig. 3).

\section{Preparation of candesartan cilexetil solid self- nanoemulsifying drug delivery systems}

Adsorbing of four liquid SNEDDS formulations on to two different set of solid adsorbent carrier mixtures resulted in eight white, fluffy and free-flowing powders with a porous structure and this will overcome the problem of stability associated with liquid dosage form and will improve patient compliance.

Evaluations of candesartan cilexetil solid selfnanoemulsifying drug delivery systems Determination of powder flowing properties

Various micromeritic properties of SSNEDDS formulations of CC are shown in (Table 10). Solid selfnanoemulsifying formulations were prepared to overcome the disadvantages associated with poor flowability of pure CC powder which has an angle of repose about
$(67.5683 \pm 0.3111)$, Hausner's ratio of $(1.7701 \pm 0.0359)$ and Carr's index of $(40.3480 \% \pm 0.1589 \%)$.

Results showed that all CC SSNEDDS formulations have good flow properties. From results gained, it was found that all powders prepared have angle of repose ranges between $25.1833 \pm 0.0060$ and $28.7171 \pm 0.1557$, Hausner's ratio is in the run of $(1.0349 \pm 0.0043$ to $1.1106 \pm 0.0004)$ and Carr's index falls into the latitude of $(3.4751 \% \pm 0.4301 \%$ to $9.6397 \% \pm 0.3722 \%)$, which indicate good flowing and compressing properties of powder.

\section{In vitro drug dissolution and kinetics of release in various media}

The dissolution of hard gelatin capsules filled with CC SSNEDDS eight formulations in $0.1 \mathrm{~N} \mathrm{HCl}$ medium (pH 1.2) with $0.5 \%$ of tween 20 at $37{ }^{\circ} \mathrm{C}$ results are presented in (Fig. 4). It could be speculated from the results gained that all CC SSNEDDS formulations resulted in a spontaneous formation of NEs with a small droplet size in zero order release model. The amount of CC released

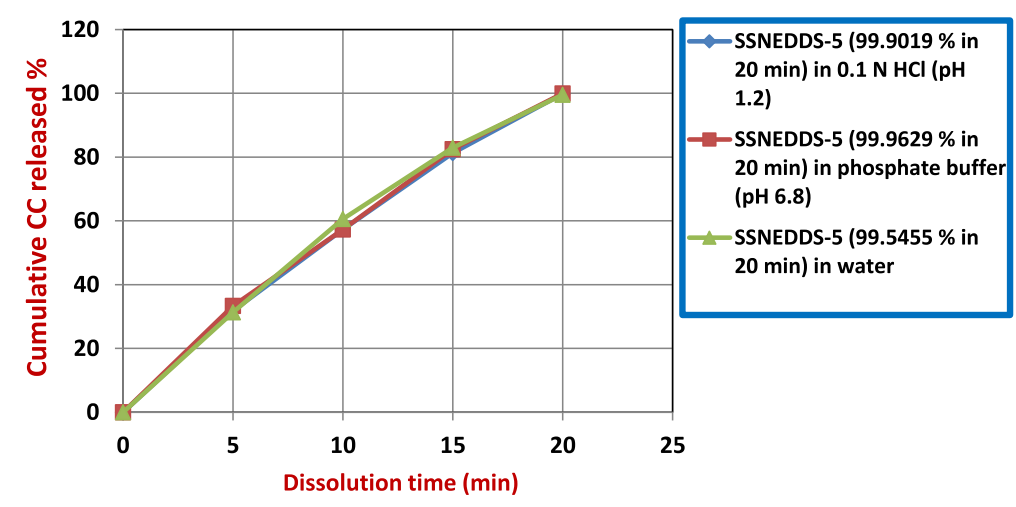

Fig. 6 A comparative dissolution profile of SSNEDDS-5 in different dissolution media 
Table 11 Release kinetics of candesartan cilexetil form SSNEDDS-5 in different media

\begin{tabular}{llllllll}
\hline F-code & $\begin{array}{l}\text { Zero order } \\
\left(R^{2}\right)\end{array}$ & $\begin{array}{l}\text { First order } \\
\left(R^{2}\right)\end{array}$ & $\begin{array}{l}\text { Higuchi } \\
\left(R^{2}\right)\end{array}$ & $\begin{array}{l}\text { Hixson Crowell } \\
\left(R^{2}\right)\end{array}$ & \multicolumn{2}{l}{ Korsmeyer and Peppas } \\
\cline { 6 - 8 } & 0.9909 & 0.7158 & 0.9579 & 0.7776 & 0.9522 & 1.5490 & Supercase II Transport \\
\hline $\begin{array}{l}\text { SSNEDDS-5 in 0.1 N HCl } \\
(p H \text { 1.2) }\end{array}$ & 0.9885 & 0.7089 & 0.9618 & 0.7708 & 0.9483 & 1.5485 & Supercase II Transport \\
$\begin{array}{l}\text { SSNEDDS-5 in phosphate } \\
\text { buffer (pH 6.8) }\end{array}$ & 0.9849 & 0.7142 & 0.9610 & 0.7745 & 0.9527 & 1.5558 & Supercase II Transport \\
\begin{tabular}{l} 
SSNEDDS-5 in water \\
\hline
\end{tabular}
\end{tabular}

percent from different SSNEDDS formulations varied according to adsorbent mixture type and Smix ratio.

In vitro drug release from CC self-nanoemulsifying capsules prepared by different adsorbent mixture was higher for formulations containing avicel 101 with aerosil 200 mixture than formulations adsorbed onto a mixture of avicel 101 plus dibasic calcium phosphate anhydrous mixture. Adsorbent particle size may be the primary factor that influences drug release from various SSNEDDS formulations (Amrutkar et al. 2014).

The release of drug decreased with increasing adsorbent particle size because of entrapment of drug in deeper voids of larger particles and a narrow surface area interacting with aqueous dissolution medium (Sohn et al. 2012). Small adsorbent particle size with its large surface area exposed and highly porous structure lead to a better soaking of drug and more contact with dissolution medium, which also increases the $\mathrm{CC}$ dissolution rate (Krstić et al. 2015).

Moreover, an excipient such as aerosil 200 enhances dissolution of CC to a large extent. It is typical of many fine inorganic powder grades like aerosil 200 has a particle size of about $15 \mathrm{~nm}$ diameter in concomitant with large surface area exposed around (100-400 $\mathrm{m}^{2} / \mathrm{g}$ ), whereas dibasic calcium phosphate anhydrous has porous spheres with average particle diameter around $94 \mu \mathrm{m}$ and surface area of $35 \mathrm{~m}^{2} / \mathrm{g}$ (Rowe et al. 2006). For this reason, the release of $\mathrm{CC}$ adsorbed onto a carrier mixture containing aerosil 200 was better than release from dibasic calcium phosphate anhydrous based formulations, which was slower.

In vitro drug release from CC self-nanoemulsifying capsules prepared by different Smix ratios were found in the following order: (Smix ratio) 4:1 $>3: 1>2: 1>1: 1$. Release of CC was more for higher ratios of Smix used when compared to the lower ratios. This may be rationalized to a better coating of carrier around the drug molecules which leads to improved solubility and dissolution rate of drug (Obitte et al. 2013). Thus, From all the results obtained, it was evident that the usage of tween 80 with poloxamer 407 mixture: transcutol HP at 3:1 and 4:1 ratio were the most advantageous in dissolution term than other ratios, although 4:1 ratio
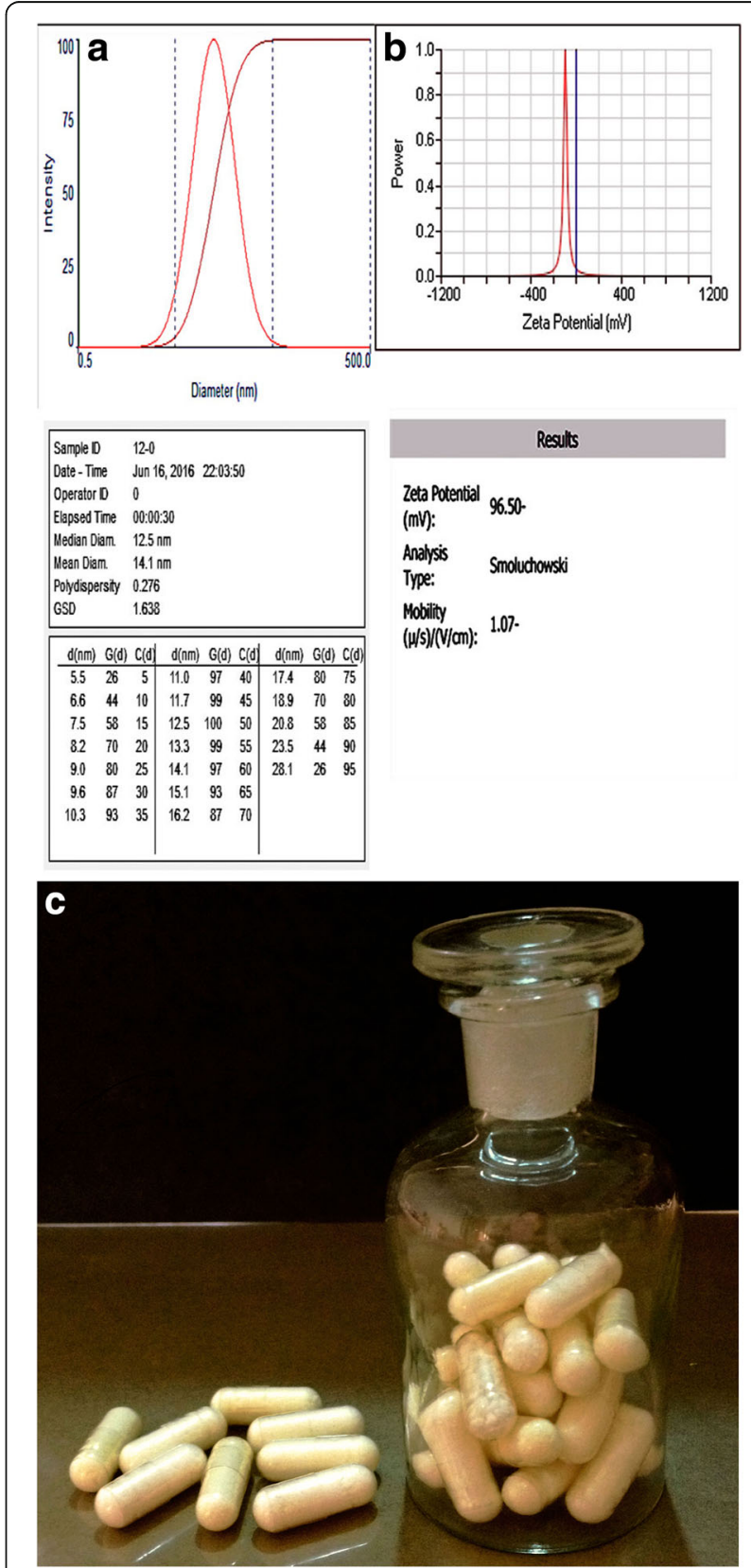

Fig. 7 Physical characteristics of SSNEDDS-5 (optimum formula) presenting: a) Particle size distribution, b) Zeta potential, and c) Digital picture of SSNEDDS-5 in capsules 
formulations have a higher particle size distribution than 3:1 ratio.

This could be attributed to the higher amount of liquid vehicle of tween 80 and poloxamer 407 which further improve solubility and dissolution of $\mathrm{CC}$ in addition to the large surface area of nanometric drug particles. It was clear that, formula (SSNEDDS-5) showed the highest drug released percent $(99.9019 \%$ after $20 \mathrm{~min}$ ) and according to ANOVA analysis, there was a substantial difference $(P<0.05)$ between the mean dissolution rates obtained from this formula, plain CC powder $(12.5174 \%$ after $20 \mathrm{~min}$ ) and marketed tablet (Atacand $8 \mathrm{mg}$ ) $(23.1033 \%$ after $20 \mathrm{~min})$ in dissolution rate and extent (Fig. 5).

In vitro CC release from SSNEDDS-5 formula was done in phosphate buffer ( $\mathrm{pH} 6.8$ ) containing $0.35 \%$ of tween 20 and in water with $2 \%$ of tween 20 (Fig. 6) and it has shown that release of $\mathrm{CC}$ was faster in phosphate
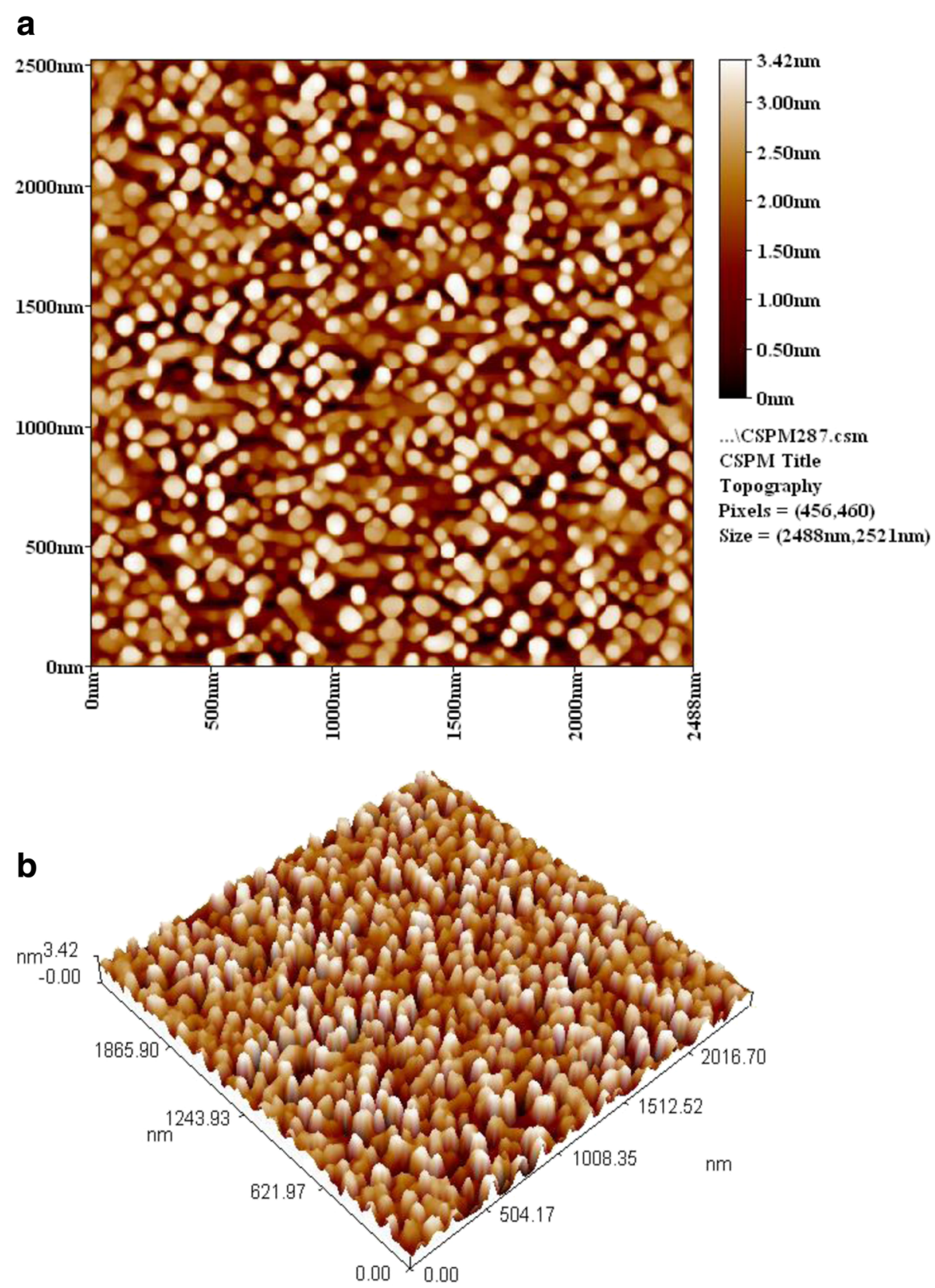

Fig. 8 Scanning probe microscopic image of optimum candesartan cilexetil solid self-nanoemulsifying drug delivery system (SSNEDDS-5) in a) Two dimensional image (scope of image: $2488 \mathrm{~nm} .2521 \mathrm{~nm}$ ), and b) Three dimensional section 


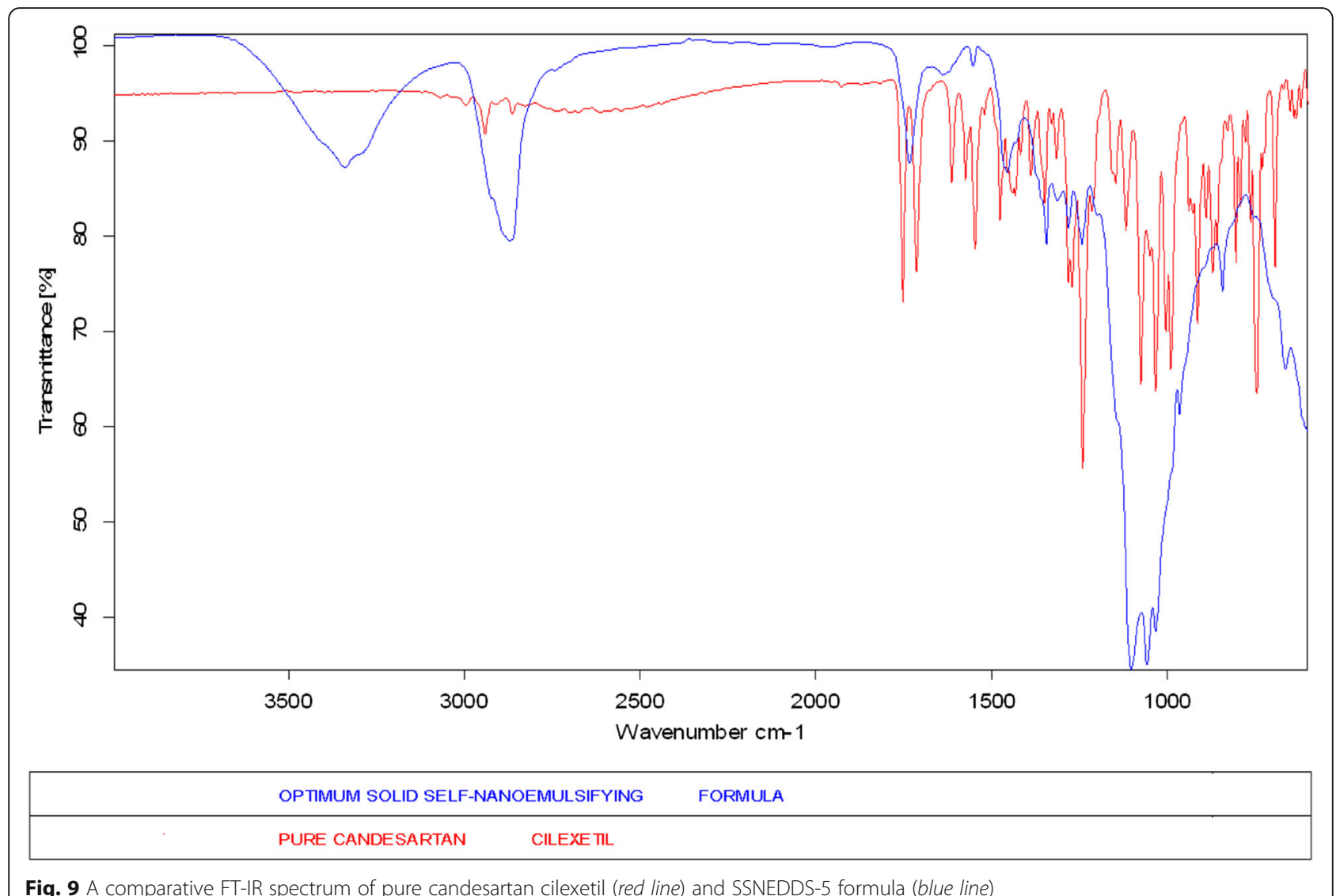

buffer ( $\mathrm{pH}$ 6.8) and lower in water compared with their release in $0.1 \mathrm{~N} \mathrm{HCl}$ medium ( $\mathrm{pH} 1.2$ ). This difference in cumulative release rate and extent in different media was due to the difference in solubility of $C C$ in various media which was following this order of solubility:

Media: phosphate buffer $(\mathrm{pH} 6.8)>0.1 \mathrm{~N} \mathrm{HCl}$ (pH 1.2) > water.

Solubility of CC $(\mathbf{m g} / \mathbf{m l}): 0.0089 \pm 0.0006>0.00617 \pm$ $0.0050>0.00034 \pm 0.0001$

Release kinetic studies of CC from the SSNEDDS-5 formulation in all media had shown the highest correlation coefficient $\left(\mathrm{R}^{2}\right)$ value was corresponding to zero order model as listed in (Table 11). According to the Korsmeyer-Pepas equation, release exponents (n) were greater than (1.00) in all release media. This indicates that supercase II transport was govern the whole release mechanism; therefore diffusion and convection controlled mechanisms play a role in the release of $\mathrm{CC}$ from SSNEDDS formulation. Also, all the results of dissolution of $\mathrm{CC}$ were conformed to united state pharmacopeia (USP) and fall within acceptable criteria (at least $75-80 \%$ amount of drug dissolved).

\section{Selection of optimum candesartan cilexetil solid self- nanoemulsifying drug delivery system}

The formula (SSNEDDS-5) was selected as an optimum self-nanoemulsifying capsule consisting of $10 \% \mathrm{w} / \mathrm{w}$ of cinnamon oil, $54 \% \mathrm{w} / \mathrm{w}$ of tween $80,13.5 \% \mathrm{w} / \mathrm{w}$ of poloxamer 407, 22.5\% w/w of transcutol HP, $200 \mathrm{mg}$ of avicel 101 and $5 \mathrm{mg}$ of aerosil 200 (Fig. 7), since it has an excellent flowing properties as indicated by having an angle of repose (25.2672 \pm 0.0243$)$, Hausner's ratio (1.0416 \pm 0.0175$)$, Carr's index $(4.3190 \% \pm 0.0928 \%)$ and fast cumulative drug

Table 12 FT-IR Characteristic functional groups of candesartan cilexetil

\begin{tabular}{lll}
\hline No. & Functional groups & Peaks $\left(\mathrm{cm}^{-1}\right)$ \\
\hline I. & -O-H Stretching & $2800-3380$ \\
II. & - C = O- Stretching & $1670-1820$ \\
III. & - C-O- Stretching & $1210-1350$ \\
IV. & -O- Substitution & $600-750$ \\
V. & Aromatic C-H Stretching & $2850-2950$ \\
\hline
\end{tabular}


release $(99.9019 \% \pm 0.0841 \%$ in $20 \mathrm{~min})$. Solubility study on this formula has shown a significant improvement in solubility of CC $(p<0.05)$ compared to water and was found to be $(524.9692 \pm 1.0652 \mathrm{mg} / \mathrm{ml})$. Presenting the drug in a highly solubilized form is expected to induce a cell-specific delivery manner with a maximum intrinsic activity of the drug. Delivery thereby limiting off-target access and improving the bioavailability of poorly soluble drug, CC.

\section{Optimum candesartan cilexetil solid self-nanoemulsifying drug delivery system further evaluations Morphology examination}

The SPM image result in (Fig. 8) showed spherical shape particles with smooth margins and average nanometric particle size of about $(57.07 \mathrm{~nm})$ of SSNEDDS-5 optimum formula. The difference in average particle size result from that obtained via particle size analyzer instrument is due to agglomeration of formula powder particles placed on a glass slide of SPM instrument. In addition, small sample loaded also considered as an another reason that made SPM probe unable to get precise statistical determination of particle size distribution (Eyjolfsson 2015).

\section{Fourier transform infrared spectroscopy}

The FT-IR spectrum of pure CC powder (Fig. 9) showed characteristic peaks ideal for pure drug powder at $2940.73 \mathrm{~cm}^{-1}$ due to aromatic (-C-H) stretching, $2862.06 \mathrm{~cm}^{-1}$ for $(\mathrm{O}-\mathrm{H})$ stretching, $1751.37 \mathrm{~cm}^{-1}$ and $1713.48 \mathrm{~cm}^{-1}$ for ester $(-\mathrm{C}=\mathrm{O})$ stretching vibration, $1270.20 \mathrm{~cm}^{-1}$ and 1315.09 due to $(-\mathrm{C}-\mathrm{O})$ stretching of carbonyl group of aromatic ester and 744.56 due to (-Osubstitution). It was found that in SSNEDDS-5 formula (Fig. 9), CC showed major characteristic peaks which were: $1733.28 \mathrm{~cm}^{-1}$ corresponding for ester $(-\mathrm{C}=\mathrm{O})$ carbonyl stretching and another peak at $1242.29 \mathrm{~cm}^{-1}$ corresponding to (-C-O) stretching in aromatic ester indicated that there was no interaction between drug and formulation excipients (Sathali and Varun 2012). All obtained peaks were within acceptable range of pure CC shown in (Table 12) (Singh et al. 2015).

Furthermore, there was a shift in the ester $(-\mathrm{C}=\mathrm{O})$ stretching vibration from $1713.48 \mathrm{~cm}^{-1}$ to $1733.28 \mathrm{~cm}^{-1}$
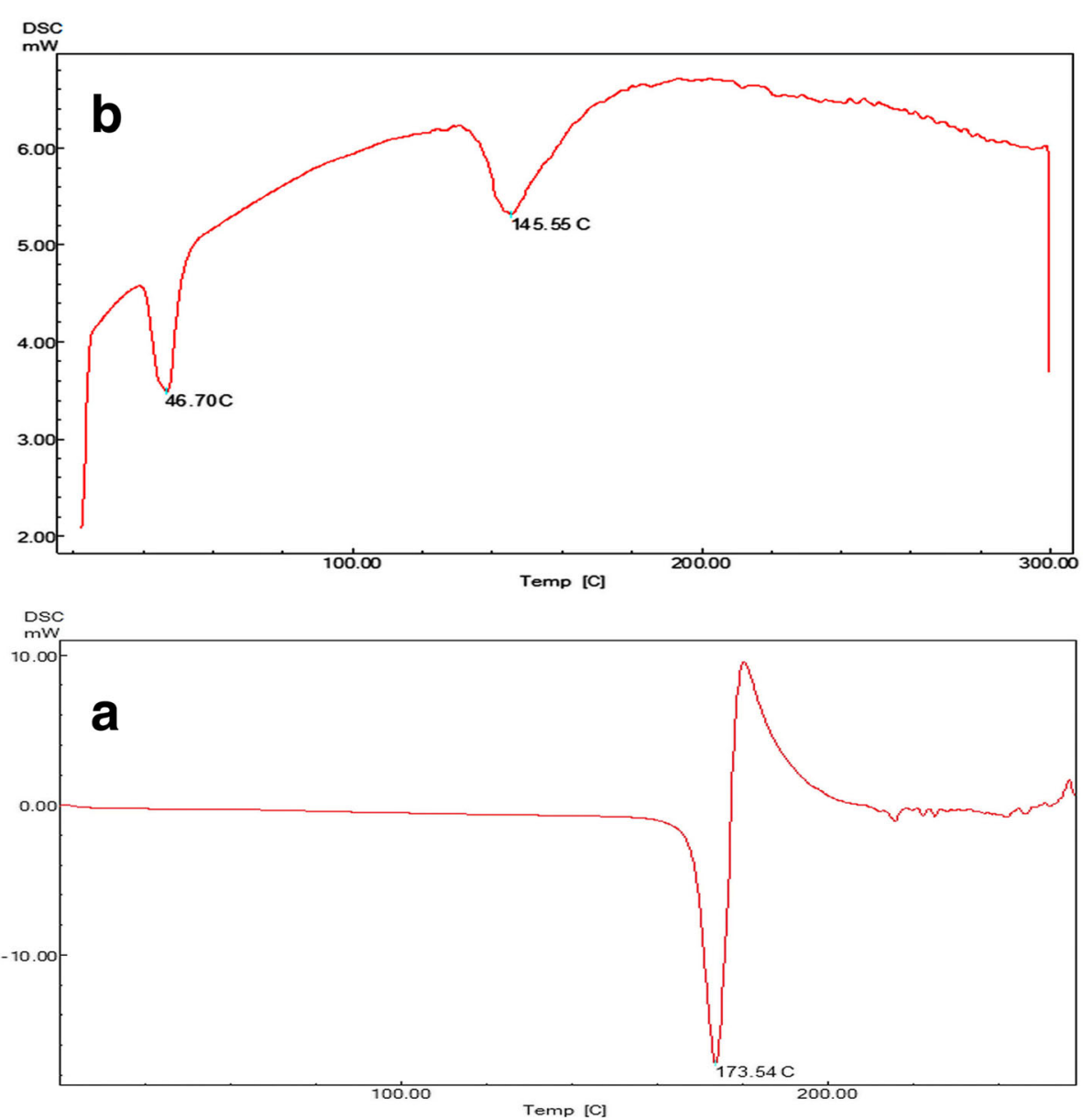

Fig. 10 Thermogram profile of (a) Pure candesartan cilexetil, and (b) Optimum formula (SSNEDDS-5) 
which may be attributed to conversion of CC from crystal form to an amorphous form (Panchal et al. 2012). The minor peaks due to $\mathrm{CC}$ were absent indicating trapping of $\mathrm{CC}$ inside the inner oily core matrix (Raghad and Hind 2015). Corresponding to $(-\mathrm{C}-\mathrm{H})$ of $\mathrm{CC}$, it was shifted from $2940.73 \mathrm{~cm}^{-1}$ to $2870.92 \mathrm{~cm}^{-1}$, which suggests the presence of hydrogen bonding, resulting in an increase in the solubility of CC (Devi et al. 2014).

\section{Differential scanning calorimetry}

Results of DSC pattern for pure CC and the optimum SSNEDDS-5 formula is shown in (Fig. 10). Pure CC showed a characteristic endothermic peak at $\left(173.54{ }^{\circ} \mathrm{C}\right)$ which indicating its melting point and conforms the reported range of $\left(160{ }^{\circ} \mathrm{C}-175{ }^{\circ} \mathrm{C}\right)$ (Reddy and Navaneetha 2015). No representative peak of $C C$ was observed for the SSNEDDS-5 formula, indicating that the drug was present in an amorphous form or in a molecularly dissolved state in cinnamon oil core of SSNEDDS-5 (Suresh et al. 2007).

It is important to remind that in the preparation of SSNEDDS-5 formula, CC was dissolved in cinnamon oil and mixed with tween 80 , poloxamer 407 , transcutol HP and subsequently was adsorbed via a solid carrier mixture. This allowed homogeneous dispersion of the $\mathrm{CC}$ in the oily phase and did not allow the drug to crystallize

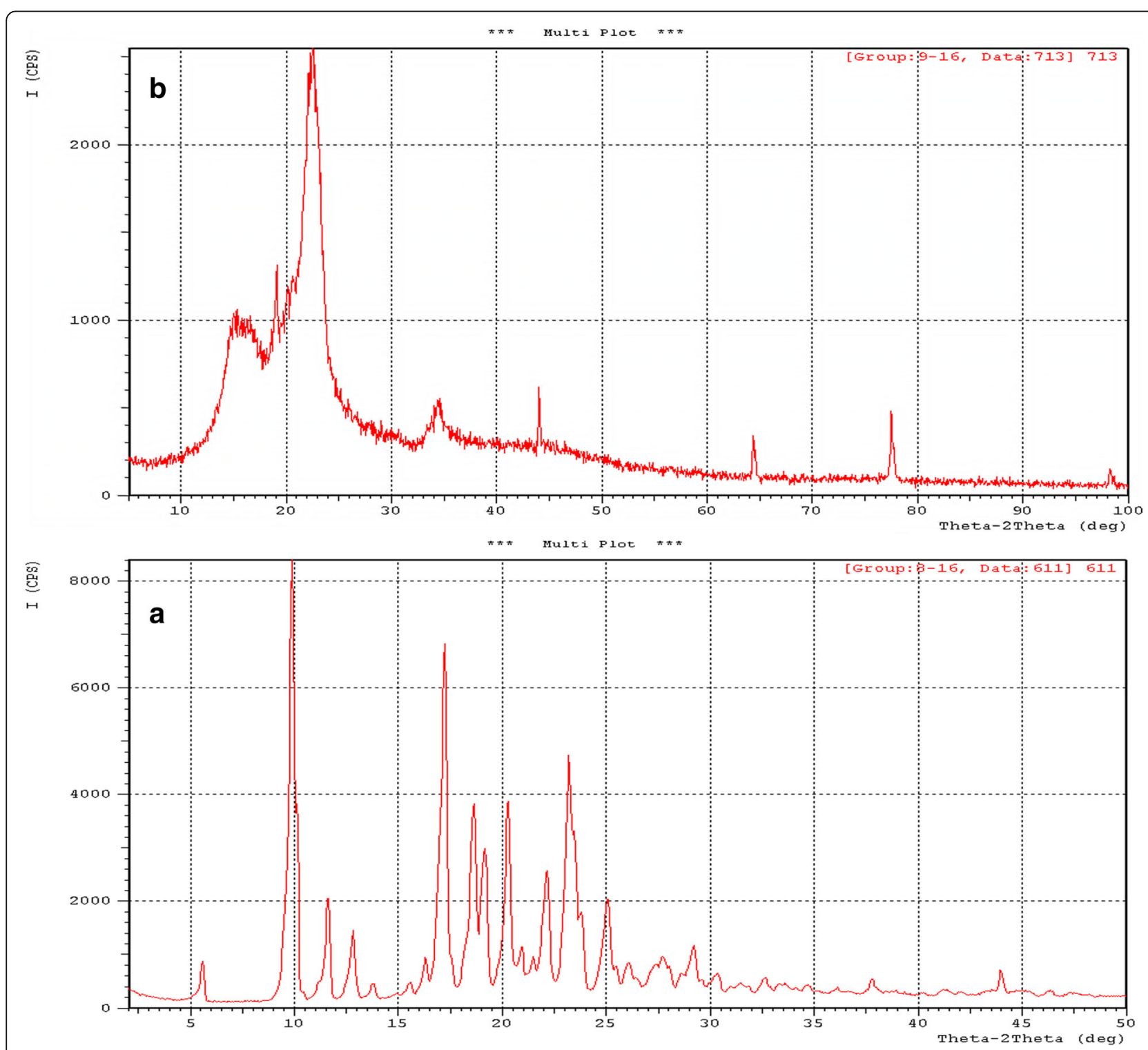

Fig. 11 The X-ray powder diffractogram of (a) pure candeartans cilexetil powder, and (b) optimum candesartan cilexetil solid self- nanoemulsifying system (SSNEDDS-5) 
Table 13 Stability of candesartan cilexetil optimum solid self-nanoemulsifying capsule (SSNEDDS-5)

\begin{tabular}{|c|c|c|c|c|}
\hline \multirow[t]{2}{*}{ No. } & \multirow[t]{2}{*}{ Tests } & \multicolumn{3}{|c|}{ Results at temperature $40^{\circ} \mathrm{C}$} \\
\hline & & Initial value & After 1 month & After 3 months \\
\hline I. & Particle size (nm) & 14.1 & 15.1 & 17.1 \\
\hline II. & PDI & 0.267 & 0.257 & 0.218 \\
\hline III. & Zeta potential (mV) & -96.50 & -95.54 & -93.55 \\
\hline IV. & Dissolution & $99.9019 \pm 0.0841$ & $99.6020 \pm 0.0434$ & $98.8514 \pm 0.4937$ \\
\hline
\end{tabular}

(Selvam and Kulkarni 2014; Cekić et al. 2015). Besides that, a new peak appeared at $\left(145.55{ }^{\circ} \mathrm{C}\right)$ in the optimum SSNEDDS-5 formula. This peak corresponds to melting of the whole system (Patil et al. 2013). Finally, regarding endothermic peak at $\left(46.70{ }^{\circ} \mathrm{C}\right)$ corresponding to avicel 101 was appeared confirming its ability to maintain its crystalline structure, but in a reduced intensity state due to the presence of cinnamon oil, tween 80, poloxamer 407 and transcutol HP.

\section{$X$-ray powder diffractometry}

The X-ray diffractogram of pure CC and SSNEDDS-5 formula is shown in (Fig. 11). It was found that X-ray diffraction pattern of pure $\mathrm{CC}$ revealed the presence of the drug in a crystalline state as it showed sharp distinct peaks notably at $2 \theta$ diffraction angles of $9.9819^{\circ}$, $17.2137^{\circ}, 18.6489^{\circ}, 19.8632^{\circ}, 21.5225^{\circ}, 23.8034^{\circ}, 25.5001^{\circ}$, $27.7464^{\circ}$ and $29.1848^{\circ}$ which match the reported values (Krishna et al. 2013). The results showed the absence of obvious peaks representing crystals of $\mathrm{CC}$ in optimum formula (SSNEDDS-5) indicating that the drug was in an amorphous or disordered crystalline phase in the oily inner core. The XRPD of SSNEDDS-5 formula showed only three sharp diffraction peaks at $2 \theta$ angles of $15.6217^{\circ}$, $20.5113^{\circ}$ and $22.5252^{\circ}$ belonging to avicel 101 , indicating that it is the only component which maintained its crystalline structure.

\section{Stability study}

The results tabulated in (Table 13) showed that there was no marked difference between initial samples and aged samples of SSNEDDS-5 formula after three months storage. This implying that there was little or no degradation of $\mathrm{CC}$ and/or excipients used in the SSNEDDS-5 formula within this period of time and it possesses a good storage capacity and thermodynamic stability for drug delivery. From Arrhenius plot, the expiration date was calculated to be about 4.366 years. It could be judged from the results gained, that inclusion of poloxamer 407 (polymeric surfactant) has been shown to be quite successful regarding stabilization, since there will be a synergistic stabilizing effect together with tween 80 ( $\mathrm{Li}$ et al. 2016).

\section{Conclusion}

Based on all results gained, it has been established that SSNEDDS with its ability to produce a nanometric dispersion of controllable size modulates the encapsulated model drug (CC) solubility, wettability, dissolution and stability in the desired fashion than did the conventional dosage form. The SSNEDDS-5 formula composed of $10 \%$ $\mathrm{w} / \mathrm{w}$ of cinnamon oil, $54 \% \mathrm{w} / \mathrm{w}$ of tween $80,13.5 \% \mathrm{w} / \mathrm{w}$ of poloxamer $407,22.5 \% \mathrm{w} / \mathrm{w}$ of transcutol HP adsorbed on a mixture of avicel 101 and aerosil 200 in 40:1 ratio showed good flow properties and best drug release, proving that delivering the drug in a highly solubilized form and rapidly dispersed manner could be achieved through proper design of SSNEDDS formulations.

\section{Abbreviations \\ ACE: Angiotensin converting enzyme; ANOVA: Analysis of variance; AT1: Angiotensin II type-1; BCS: Biopharmaceutical classification system; CC: Candesartan cilexetil; $\mathrm{cm}$ : Centimeter; $\mathrm{cm}^{-1}$ : Reciprocal centimeter; DSC: Differential scanning calorimetry; FT-IR: Fourier transform infrared; g: Gram; GRAS: Generally regarded as safe; HLB: Hydrophilic/lipophilic balance; h: Hour; Log P: Base-10 logarithm of the permeability coefficient; $\mathrm{m}^{2}$ : Square meter; mg: Milligram; min: Minute; ml: Milliliter; mV: Millivolt; $\mathrm{N}$ : Normal; NEs: Nanoemulsions; $\mathrm{nm}$ : Nanometer; No: Number; NTU: Nephelometric turbidity unit; o/w: Oil in water; PDI: Polydispersity index; $\mathrm{pH}$ : Minus Logarithm $\left[\mathrm{H}^{+}\right]$; $\mathrm{RH}$ : Relative humidity; Rl: Refractive index; rpm: Revolution per minute; Smix: Surfactant/co-surfactant mixture; SNEDDS: Self-nanoemulsifying drug delivery system; SPM: Scanning probe microscopy; SSNEDDS: Solid self-nanoemulsifying drug delivery; USP: United state pharmacopeia; UVNis: Ultraviolet/Visible; w/o: Water in oil; w/w $\%$ : Weight by weight percent; XPRD: X-ray powder diffractometery; $\lambda_{\text {max }}$ : Wave length with maximum absorbance}

\section{Funding}

None.

Authors' contributions

Both authors read and approved the final manuscript.

\section{Competing interests}

The authors declare that they have no competing interests.

\section{Publisher's Note}

Springer Nature remains neutral with regard to jurisdictional claims in published maps and institutional affiliations.

Received: 24 January 2017 Accepted: 9 May 2017 Published online: 15 June 2017

\section{References}

Ahmad J, Mir SR, Kohli K, Chuttani K, Mishra AK, Panda AK, Amin S (2014) Solid-nanoemulsion preconcentrate for oral delivery of paclitaxel: formulation design, biodistribution, and $\gamma$ scintigraphy imaging. BioMed Res Inter 2014:1-12 
Amrutkar C, Salunkhe K, Chaudhary S (2014) Study on self nanoemulsifying drug delivery system of poorly water soluble drug rosuvastatin calcium. World J Pharm Res 3(4):2137-2151

Aulton ME, Taylor KM (2013) Aulton's pharmaceutics: the design and manufacture of medicines, 4th edn. Edinburgh, Elsevier Health Sciences

Bandyopadhyay S, Bhuria L, Lal D (2013) An explicit review on quantitative estimation of candesartan cilexetil employing various analytical techniques. Pharma Anal Acta 4(6):1-7. doi:10.4172/2153-2435.1000254

Beale JM, Block J, Hill R (2010) Organic medicinal and pharmaceutical chemistry, 12th edn. Lippincott Williams and Wilkins, Philadelphia

Bieger D, Hein L, Lüllmann H, Mohr K (2005) Color atlas of pharmacology, 3rd edn. Thieme, Stuttgart

Bouchemal K, Briançon S, Perrier E, Fessi H (2004) Nano-emulsion formulation using spontaneous emulsification: solvent, oil and surfactant optimization. Int J Pharmaceutics 280(1):241-251. doi:10.1016/j.jpharm.2004.05.016

Cekić ND, Đorđević SM, Savić SR, Savić SD (2015) A full factorial design in the formulation of diazepam parenteral nanoemulsions: physicochemical characterization and stability evaluation. Adv Technol 4(1):69-77

Chavda H, Patel J, Chavada G, Dave S, Patel A, Patel C (2013) Self-nanoemulsifying powder of isotretinoin: preparation and characterization. J Powder Technol 1-9. doi:10.1155/2013/108569

Czajkowska-Kośnik A, Szekalska M, Amelian A, Szymańska E, Winnicka K (2015) Development and evaluation of liquid and solid self-emulsifying drug delivery systems for atorvastatin. Molecules 20(12):21010-21022. doi:10.3390/ molecules201219745

Darwhekar GN, Jain DK, Chouhan J (2012) Biopharmaceutical classification of candesartan and candesartan cilexetil. Asi J Pharm Life Sci 2(2):295-302

Dash RN, Mohammed H, Humaira T, Ramesh D (2015) Design, optimization and evaluation of glipizide solid self-nanoemulsifying drug delivery for enhanced solubility and dissolution. Saudi Pharmaceutical J 23(5):528-540. doi:10.1016/j. jsps.2015.01.024

Devi S, Peddinti D, Pinnika A (2014) Formulation and evaluation of solid dispersion tablets of poorly water soluble drug candesartan cilexetil using poloxamer 407. Int J Pharm Sci Rev Res 29(1):67-73

Dey S, Jha SK, Malakar J, Gangopadhyay A (2012) Improvement of bioavailability of poorly soluble drugs through delivery system. J Pharm SciTech 1(2):6-11

Ebrahimi P, Ebrahim-Magham B, Pourmorad F, Honary S (2013) Ferulic acid lecithin-based nano-emulsions prepared by using spontaneous emulsification process. Iran J Chem Chem Eng 32(3):17-25

Eid AM, Elmarzugi NA, El-Enshasy HA, Arafat OM (2013) A novel Swietenia macrophylla oil self-nanoemulsifying system: development and evaluation. Int J Pharm Pharm Sci 5(Suppl 3):639-644

Elgadira MA, Adam A (2014) Selected drug delivery systems based on nanoemulsion. World J Pharm Res 3(2):1796-1809

Elnaggar YS, El-Massik MA, Abdallah OY (2009) Self-nanoemulsifying drug delivery systems of tamoxifen citrate: design and optimization. Int J Pharm 380(1): 133-141. doi:10.1016/j.ijpharm.2009.07.015

Eyjolfsson R (2015) Design and manufacture of pharmaceutical tablets. Elsevier, London

Fathi M, Mozafari MR, Mohebbi M (2012) Nanoencapsulation of food ingredients using lipid based delivery systems. Trends Food Sci Technol 23(1):13-27. doi:10.1016/j.tifs.2011.08.003

Frayn K (2005) Cardiovascular disease: diet, nutrition and emerging risk factors. The report of a british nutrition foundation task force. Blackwell, Oxford

Giannini C, Ladisa M, Altamura D, Siliqi D, Sibillano T, De Caro L (2016) X-ray diffraction: a powerful technique for the multiple-length-scale structural analysis of nanomaterials. Crystals 6(87):1-22. doi:10.3390/cryst6080087

Gupta AK, Mishra DK, Mahajan SC (2011) Preparation and in-vitro evaluation of self emulsifying drug delivery system of antihypertensive drug valsartan. Int J Pharm Life Sci 2(3):633-639

Husain A, Azim M, Mitra M, Bhasin PS (2011) A review on candesartan: pharmacological and pharmaceutical profile. J Appl Pharma Sci 1(10):12-17

Jane PFB, Guo JH, Chaubal MV (2006) Excipient development for pharmaceutical biotechnology and drug delivery systems, 3rd edn. Informa Healthcare, USA

Kalepun S, Manthina M, Padavala V (2013) Oral lipid-based drug delivery systems-an overview. Acta Pharm Sin B 3(6):361-372. doi:10.1016/j.apsb.2013.10.001

Kamalakkannan V, Puratchikody A, Ramanathan L (2013) Development and characterization of controlled release polar lipid microparticles of candesartan cilexetil by solid dispersion. Res Pharm Sci 8(2):125-136
Kassem AA, Marzouk MA, Ammar AA, Elosaily GH (2010) Preparation and in vitro evaluation of self-nanoemulsifying drug delivery systems (SNEDDS) containing clotrimazole. Drug Discoveries Therapeutics 4(5):373-379

Kolesar JM, Vermeulen LC (2016) Top 300 pharmacy drug cards-2016/2017. McGraw-Hill Education, New York

Krishna HP, Srinivasan B, Rajamanickam D, Veerabhadraiah BB, Varadharajan M (2013) Solubility and dissolution enhancement of candesartan cilexetil by liquisolid compacts. Pharmaceutics Drug Deliv Res 2(2):1-10. doi:10.4172/ 2325-9604.1000115

Krstić M, Ražić S, Vasiljević D, Spasojević Đ, Ibrić S (2015) Application of experimental design in the examination of the dissolution rate of carbamazepine from formulations. Characterization of the optimal formulation by DSC, TGA, FT-IR and PXRD analysis. J the Serb Chem Soc 80(2):209-222. doi:10.2298/JSC030814114K

Kumar M, Pathak K, Misra A (2009) Formulation and characterization of nanoemulsion-based drug delivery system of risperidone. Drug Dev Ind Pharm 35(4):387-395. doi:10.1080/03639040802363704

Lachman L, Lieberman HA (1990) Pharmaceutical dosage forms, parenteral medications. M. Dekker, New York

Li M, Azad M, Davé R, Bilgili E (2016) Nanomilling of drugs for bioavailability enhancement: a holistic formulation-process perspective. Pharmaceutics 8(17):1-35. doi:10.3390/pharmaceutics8020017

Maravajhala V, Papishetty S, Bandlapalli S (2012) Nanotechnology in development of drug delivery system. Int J Pharm Sci Res 3(1):84-96

Mehta MR, Machhaliya RY, Patel CN, Daraji HM (2014) Formulation and evaluation of sublingual tablet of candesartan cilexetil. Int J Pharm Res BioSci 3(2):900-925

Moffat AC, David Osselton M, Brian W (2011) Clarke's analysis of drugs and poisons, 4th edn. Pharmaceutical Press, London

Mohanrao BM, Sundar PS, Nagsen S (2011) Preparation and characterization of solid self microemulsifying drug delivery system by adsorbent technique to improve dissolution profile of poorly aqueous soluble drug Ramipril. Int Res J Pharm 2(6):85-90

Muhamad II, Selvakumaran S, Lazim NA (2014) Designing polymeric nanoparticles for targeted drug delivery system. Nanomedicine 287-313

Obitte NC, Rohan LC, Adeyeye CM, Parniak MA, Esimone CO (2013) The utility of self-emulsifying oil formulation to improve the poor solubility of the anti HIV drug CSIC. AIDS Res Ther 10(1):1-9

Panchal D, Patel U, Bhimani B, Daslaniya D, Patel G (2012) Formulation and evaluation of sustained release matrix tablets of candesartan cilexetil. Int J Pharm Res BioSci 1(4):75-101

Patel ND, Patel YB, Mankad AU (2012) Techniques to improve the solubility of poorly soluble drugs. Int J Pharm Life Sci 3(7):1828-1832

Patil S, Patil V, Shete A, Doijad R (2013) Design, development and in vitro characterization of self emulsifying drug delivery system for Irbesartan. Iran J Pharm Sci 9(2):67-80

Prabhakar K, Afzal SM, Surender G, Kishan V (2013) Tween 80 containing lipid nanoemulsions for delivery of indinavir to brain. Acta Pharm Sin B 3(5):345-353

Prajapati ST, Joshi HA, Patel CN (2013) Preparation and characterization of selfmicroemulsifying drug delivery system of olmesartan medoxomil for bioavailability improvement. J Pharmaceutics 2013:1-9. doi:10.1155/2013/ 728425

Raghad AN, Hind EZ (2015) Enhancement of candesartan cilexetil dissolution rate by using different methods. Asi J Pharm Clin Res 8(1):320-326

Rahman MA, Harwansh R, Mirza MA, Hussain S, Hussain A (2011) Oral lipid based drug delivery system (LBDDS): formulation, characterization and application: a review. Curr Drug Deliv 8(4):1-16. doi:10.2174/156720111795767906

Raval C, Joshi N, Patel J, Upadhyay UM (2012) Enhanced oral bioavailability of olmesartan by using novel solid self emulsifying drug delivery system. Int J Adv Pharmaceutics 2(2):82-92

Reddy BV, Navaneetha K (2015) Formulation and evaluation of orodispersible tablets of candesartan. Pharm Innov J 4(1):25-32

Reddy MS, Sowjanya N (2015) Formulation and in-vitro characterization of solid self nanoemulsifying drug delivery system (s-SNEDDS) of simvastatin. J Pharm Sci Res 7(1):40-48

Rowe RC, Sheskey PJ, Weller PJ (2006) Handbook of pharmaceutical excipients, 6th edn. Pharmaceutical press, London

Sarkar B, Hardenia S (2011) Microemulsion drug delivery system: for oral bioavailability enhancement of glipizide. J Adv Pharm Educ Res 1(4):195-200

Sathali AA, Varun J (2012) Formulation, development and in vitro evaluation of candesartan cilexetil mucoadhesive microbeads. Int J Curr Pharm Res 4(3): $109-118$ 
Selvam RP, Kulkarni PK (2014) Design and evaluation of self nanoemulsifying systems for poorly water soluble HIV Drug. J PharmaSciTech 4(1):23-28

Selvam PR, Kulkarni PK, Dixit M (2013) Preparation and evaluation of selfnanoemulsifying formulation of efavirenz. Ind J Pharm Edu Res 47(1):47-54

Shafiq S, Shakeel F (2009) Effect of labrasol on self-nanoemulsification efficiency of ramipril nanoemulsion. Die Pharmazie-An Int J Pharm Sci 64(12):812-817. doi:10.1016/j.apsb.2013.08.001

Singh J, Umadevi SK, Vardhan S, Lachoriya M, Rajeswari G, Kasturibai B (2015) Solubility enhancement of candesartan cilexetil by using different hydrotropic agents. Eur J Pharm Med Res 2(1):339-353

Sohn Y, Lee SY, Lee GH, Na YJ, Kim SY, Seong I, Lee BJ, Kuh HJ, Lee J (2012) Development of self-microemulsifying bilayer tablets for $\mathrm{pH}$-independent fast release of candesartan cilexetil. Die Pharmazie-An Int J Pharm Sci 67(11): 917-924

Soni GC, Prajapati SK, Chaudhari N (2014) Self nanoemulsion: advance form of drug delivery system. World J Pharm Pharm Sci 3(10):410-436

Suresh G, Manjunath K, Venkateswarlu V, Satyanarayana V (2007) Preparation, characterization, and in vitro and in vivo evaluation of lovastatin solid lipid nanoparticles. AAPS PharmSciTech 8(1):E1-E9

Sureshkumar R, Gowthamarajan K, Bhavani P (2015) Nanoemulsion for lymphatic absorption: investigation of fenofibrate nanoemulsion system for lymphatic uptake. Int J ChemTech Res 7(2):832-841

Sweetman SC (2009) Martindale: the complete drug reference, 36th edn. Pharmaceutical press, London

Tarkase KN, Damale PS, Kapare PS, Lagad VA (2014) Formulation and evaluation of supersaturable self nano-emulsifying drug delivery system of poorly water soluble atorvastatin calcium. Asi J Pharm Res Dev 2(4):22-33

Thassu D, Deleers M, Pathak W (2007) Nanoparticulate drug delivery systems. Informa Healthcare, New York

Tiwari SB, Amiji MM (2006) Improved oral delivery of paclitaxel following administration in nanoemulsion formulations. J Nanosci Nanotechno 6(8):1-7. doi:10.1166/jnn.2006.440

Vinay CH, Ahmed MG (2015) Formulation and evaluation of mucoadhesive buccal tablets of candesartan. J Drug Deliv Therapeutics 1(4):369-386. doi:10.1155/2013/583536

Vuddisa SK, Subramanian S, Raavi S (2014) Preparation and characterization of candesartan cilexetil solid lipid nanoparticulate capsules. Int J Pharma Res $\operatorname{Rev} 3(12): 26-31$

Wadhwa J, Nair A, Kumria R (2012) Emulsion forming drug delivery system for lipophilic drugs. Acta Pol Pharm 69(2):179-191

Yadav PS, Yadav E, Verma A, Amin S (2014) Development, characterization, and pharmacodynamic evaluation of hydrochlorothiazide loaded selfnanoemulsifying drug delivery systems. Sci World J 1-10. doi:10.1155/2014/ 274823.

Yasser M, Gad S, El-sayed M, Ghorab M (2013) The effect of converting liquid valsartan SNEDDS into solid SNEDDS using different solid carriers on its performance. Int J Bio Pharm Res 4(12):1015-1026

\section{Submit your manuscript to a SpringerOpen ${ }^{\circ}$ journal and benefit from:}

- Convenient online submission

- Rigorous peer review

- Open access: articles freely available online

- High visibility within the field

- Retaining the copyright to your article

Submit your next manuscript at $\gg$ springeropen.com 